\title{
KAJIAN EROSI DAN SEDIMENTASI PADA DAERAH ALIRAN SUNGAI DENIANG KABUPATEN BANGKA
}

\author{
Endang Setyawati Hisyam \\ Email : hisyam.endang@gmail.com \\ Staf Pengajar Jurusan Teknik Sipil, Universitas Bangka Belitung, Bangka \\ Fajar Shodiq \\ Email : hisyam.endang@gmail.com \\ Alumni Teknik Sipil Universitas Bangka Belitung
}

\begin{abstract}
ABSTRAK
Daerah Aliran Sungai (DAS) Deniang terletak di Desa Deniang Kabupaten Bangka dengan luas DAS $\pm 7.768,42$ Ha. Penyebab kerusakan DAS ini adalah aktifitas penambangan, perubahan tata guna lahan yang semula hutan menjadi tempat permukiman dan lahan pertanian yang tidak dikelola dengan baik sehingga dampak yang ditimbulkan adalah berkurangnya hutan sebagai pelindung alam, tanah mudah terkikis atau terjadinya erosi. Metode analisis yang dilakukan pada penelitian ini untuk mengetahui besarnya erosi yang terjadi dengan pendekatan USLE (Universal Soil Loss Equation). Sedangkan untuk analisis sedimentasi pada Sungai Deniang menggunakan metode Duboys dan metode Meyer Peter Muller. Berdasarkan analisis yang telah dilakukan dengan metode USLE, maka diperoleh besar erosi total pada DAS Deniang yaitu 2.596.471,761 ton/tahun dengan klasifikasi bahaya erosi Kelas IV (Berat). Penyebab erosi di DAS Deniang disebabkan oleh Nilai $\mathrm{P}$ (faktor manajemen tanah) $=1$, menunjukkan bahwa pada DAS ini tidak ada upaya konservasi tanah. Dari hasil perhitungan sedimen total yang terjadi Sungai Deniang menggunakan metode Duboys pada bagian hulu sebesar 114,124 Ton/Tahun, bagian tengah 7.728,545 Ton/Tahun dan pada bagian hilir sebesar 12.531,282 Ton/Tahun. Kemudian hasil sedimen total menggunakan rumus Meyer Peter Muller dibagian hulu sebesar 302,671 Ton/Tahun, bagian tengah 2.399,876 Ton/Tahun dan pada bagian hilir sebesar 4336,673 Ton/Tahun.
\end{abstract}

Kata kunci : Erosi, Sedimentasi, Perubahan Tata Guna Lahan

PENDAHULUAN

Menurut Arsyad dalam Banuwa, 2013 Erosi adalah peristiwa pindahnya atau terangkutnya tanah atau bagian bagian tanah dari suatu tempat ke tempat lain oleh media alami. Pada peristiwa erosi, tanah atau bagian bagian tanah dari suatu tempat terkikis dan terangkut kemudian diendapkan pada suatu tempat lain.

Menurut Asdak, 2014 Erosi merupakan suatu proses atau peristiwa hilangnya lapisan permukaan tanah atas, baik disebabkan oleh pergerakan air maupun angin. Proses erosi terdiri atas tiga bagian yang berurutan: penglupasan (detachment), pengangkutan (transportation), dan penggendapan (sedimentation). Pengendapan merupakan lanjutan dari pengelupasan dan pengangkutan partikel-partikel tanah yang disebut juga sedimentasi. Secara umum, terjadi erosi ditentukanolehfaktorfaktoriklim (terutama intensitas hujan), topografi, karakteristik tanah, vegetasi penutup tanah, dan tata guna lahan. Ada dua penyebab utama proses terjadinya erosi, ialah tetesan butir-butir air hujan dan aliran permukaan. Erosi dapat meningkat seiring dengan aktifitas manusia terhadap tata guna lahan yang meliputi 
penggundulan hutan, kegiatan kontruksi/ pembangunan, dan pertambangan.

Perubahan pola tata guna lahan atau alih fungsi hutan sangat kuat pengaruhnya terhadap proses erosi karena aktivitas tersebut cenderung mengakibatkan degradasi tanah, sehingga butiran-butiran tanah mudah lepas dan terbawa oleh air dan angin. (Suripin, 2004).

Sungai Deniang termasuk dalam DAS Deniang yang teletak di Desa Deniang Kabupaten Bangka dengan luas DAS $\pm 7.768,42$ Ha. Aliran Sungai Deniang tepat berada dibawah Jembatan Deniang II yang merupakan jembatan penghubung Kecamatan Belinyu dengan Kecamatan Sungailiat. Sungai Deniang merupakan sungai yang penting bagi kehidupan masyarakat yang berada disekitar sungai tersebut. Aktivitas yang berlangsung di sepanjang Sungai Deniang antara lain kegiatan pertambangan, perkebunan serta pemanfaatan air sungai untuk kebutuhan sehari-hari.

Sungai Deniang yang terbentang dari hulu terletak di daerah Desa Cit hingga kawasan hilir bermuara langsung di Pantai Pulau Tiga. Sungai Deniang menjadi salah satu sumber kehidupan masyarakat Desa Deniang dan sekitarnya serta menjadi habitat berbagai jenis ikan. Akan tetapi saat ini banyak masalah yang terjadi di Sungai Deniang. Beberapa masalah pokok yang menyebab terjadinya banjir di daerah DAS Deniang sebagian besar disebabkan masih adanya Tambang Inkonvensional (TI) yang beroperasi dari daerah hulu sungai yang menyebabkan sering terjadinya sedimentasi atau endapan serta tataguna lahan terganggu sehingga terjadi erosi. Endapan yang disebabkan oleh kegiatan pertambangan tersebut menyebabkan debit air sungai pada saat musim hujan mengalami kenaikan hingga menyebabkan banjir.

Oleh sebab itu, karena adanya erosi dan sedimentasi di DAS Deniang yang menyebabkan banjir maka perlu dilakukan Kajian Erosi dan Sedimentasi Pada Daerah Aliran Sungai Deniang Kabupaten Bangka sehingga dampak negatif yang ditimbulkan dapat diminimalisir.

\section{TINJAUAN PUSTAKA}

Penelitian yang pernah dilakukan sebelumnya terkait dengan erosi dan sedimentasi antara lain:

Fadillah (2017) dalam penelitiannya tentang Kajian erosi \& sedimentasi akibat perubahan tataguna lahan daerah aliran sungai (Studi Kasus DAS Betung Sub DAS Pebari-Jelitik Kabupaten Bangka). DAS Pebari-Jelitik, objek penelitian ini, memiliki luas $\pm 3762 \mathrm{Ha}$ dan merupakan bagian dari Betung Watershed Kabupaten Bangka yang memiliki luas 14.282 Ha. Jenis tanah adalah: Aluvial, Kambisol, dan Podsolik, sebagian besar wilayahnya adalah daerah tangkapan yang memiliki kemiringan $0 \%-8 \%$. Tutupan lahan terdiri dari rumah, tegalan/ladang, area penambangan, dan perkebunan. Besarnya erosi di DAS Pebari-Jelitik yang diperoleh dengan menggunakan persamaan USLE adalah 1.016.052,6 ton/tahun, atau rata-rata 270.083 ton/ha/tahun, yang cocok dengan kategori kelas IV (berat). Berdasarkan analisis menggunakan persamaan MayerPeter and Muler (MPM), jumlah sedimen yang masuk ke Sungai Pebari-Jeitik 
disebabkan oleh erosi tanah 38.384,78 ton/tahun di hulu, 55.119,78 ton/tahun di tengah, dan 52.753,60 ton/tahun di hilir. Penyebab erosi di Pebari Jelitik Subwatershed lebih disebabkan oleh persentase nilai C (koefisien Run Off) yang lebih dari $60 \%$ dan sangat dipengaruhi oleh penggunaan lahan. Nilai $\mathrm{P} \quad$ (faktor manajemen tanah) $=1$, menunjukkan bahwa di subwatershed tidak ada upaya konservasi tanah. Bahan erosi tanah masuk ke Sungai Pebari-Jelitik dan menyebabkan sedimentasi yang sangat tidak alami di Sungai Pebari-Jelitik. Erosi dan Sedimentasi adalah bukti nyata bahwa jumlah lahan terdegradasi di Bangka Belitung akan terus meningkat karena perubahan penggunaan lahan.

Menurut Sembiring, Amalia Ester (2014) dalam penelitiannya tentang Analisis Sedimentasi di Muara Sungai Panasen. Penelitian ini bertujuan untuk menganalisis total sedimentasi di muara Sungai Penasen yang dapat berguna dalam upaya pengelolaan sedimen di sungai. Untuk menganalisis debit sedimen digunakan debit dominan dengan data debit aliran sungai panasen selama 10 tahun. Metode yang dipakai dalam menganalisis total angkutan sedimen adalah metode Einsten dan metode Bagnold. Pengujian sampel sedimen dilakukan dilaboratorium, pengujian berupa menentukan ukuran butiran sedimen, berat jenis sedimen dan kosentrasi sedimen. Dari analisis debit aliran dominan sebesar 1,267 m3/det, diperoleh total angkutan sedimen metode Einsten sebesar 895,6224 m3/tahun dan metode Bagnold sebesar 1419,5461 $\mathrm{m}^{3} /$ tahun. Berdasarkan hasil perhitungan total angkutan sedimen di muara sungai Panasen diperoleh bahwa metode Bagnold memberikan hasil yang paling besar.

Menurut Adrianto, Bayu (2017) dalam penelitiannya tentang Analisa Laju Sedimentasi di Muara Sungai Karangsong, Kabupaten Indramayu. Penelitian ini bertujuan untuk mengetahui laju sedimentasi yang terjadi di muara sungai Karangsong. Penelitian ini dilakukan untuk mengetahui laju sedimentasi yang berkaitan dengan parameter oseanografi pasang surut dan arus laut. Penelitian ini menggunakan data utama dan data pendukung. Data utama, meliputi contoh sedimen dan data arus. Sedangkan untuk data pendukung, meliputi data pasang surut dan peta Rupa Bumi Indonesia Kota Indramayu. Pengambilan contoh sedimen dilakukan selama 15 hari menggunakan alat sediment trap dengan interval waktu pengambilan contoh sedimen selama 3 hari 1 kali pengambilan. Penempatan sediment trap dilakukan di 7 lokasi, yaitu 1 sediment trap di alur sungai, 1 sediment trap di muara sungai dan 5 sediment trap di perairan sekitar muara sungai Karangsong. Pengukuran data arus dilakukan selama 25 jam dengan interval waktu pengambilan data adalah 1 jam. Berdasarkan hasil penelitian yang diperoleh, dapat diketahui nilai laju sedimentasi yang terdapat di setiap lokasi penelitian. Lokasi 1 di alur sungai nilai laju sedimentasinya yaitu $108,8 \mathrm{~g} / \mathrm{m}^{2} /$ hari. Lokasi 2 di muara sungai nilai laju sedimentasinya yaitu 101,3 $\mathrm{g} / \mathrm{m}^{2} /$ hari. Lokasi 3-7 di perairan sekitar 
muara sungai nilai laju sedimentasinya bervariasi tetapi tidak lebih tinggi dibandingkan dengan lokasi 1 dan 2. Nilai kecepatan arus maksimum di perairan Karangsong adalah $0,08849 \mathrm{~m} / \mathrm{s}$, nilai kecepatan arus minimum adalah 0,03731 $\mathrm{m} / \mathrm{s}$, sehingga diperoleh nilai rata-rata kecepetan arusnya adalah $0,0629 \mathrm{~m} / \mathrm{s}$.

Penelitian yang dilakukan di alur sungai Bangka, Maulana,S. (2010). Penelitian dilakukan di Muara Air Kantung Sungailiat yang merupakan hilir Sungai Pepabri-Jelitik sebelum menuju laut lepas. Angkutan sedimentasi penyebab pendangkalan alur Muara Sungailiat Air Kantung yang setiap tahun terjadi di wilayah hulu dan hilir Sungai Jelitik Kecamatan Sungailiat, berdasarkan hasil penelitian terdapat selisih nilai volume sedimentasi sebesar $1.075 \mathrm{~m}^{3} /$ tahun. Volume angkutan sedimentasi yang disebabkan oleh pengaruh arus gelombang laut yang membawa bahan sedimen dari dua arah angin ke bibir sebesar 4.462 $\mathrm{m}^{3} /$ tahun, sedangkan volume bahan sedimen yang disebabkan oleh aktivitas pertaambangan illegal pada bibir pantai sebesar $252.000 \mathrm{~m}^{3} /$ tahun. Penyebab sedimentasi di alur Muara Sungai Air Kantung 98\% dikarenakan aktifitas pertambangan.

Menurut Suripin, 2004 Salah satu persamaan yang digunakan untuk memprediksi besarnya erosi lahan yang pertama dikembangkan adalah persamaan Wischmeier and Smith 1965 (dalam Williams and Berndt, 1972; Morgan, 1988; Selbe, 1993; dan Renard et.al.,1996) yang selanjutnya dikembangkan menjadi persamaan yang dikenal dan dipakai hingga sekarang yaitu USLE atau universal soil loss equation. USLE memungkinkan perencana memprediksi laju erosi rata-rata lahan tertentu pada suatu kemiringan dengan pola hujan tertentu setiap macam jenis tanah dan penerapan pengolahan lahan (tindakan konservasi lahan). USLE dirancang untuk memprediksi erosi jangka panjang dari lembar erosi (sheet erosion) dan erosi alur di bawah kondisi tertentu. Adapun Persamaan USLE bisa dilihat pada formula sebagai berikut:

$\mathrm{A} \quad=R \times K \times L S \times C \times P$

dimana :

A = banyaknya tanah tererosi dalam (ton/ha/tahun),

$\mathrm{R}$ = faktor erosivitas hujan dan air permukaan.

$\mathrm{K}=$ faktor erodibilitas tanah.

$\mathrm{LS}=$ faktor panjang dan kemiringan lereng.

$\mathrm{C}$ = faktor vegetasi penutup tanah dan pengelolaan tanaman.

$\mathrm{P}=$ faktor tindakan-tindakan konservasi tanah.

Untuk analisis sedimen pada penelitian ini, dilakukan dengan dua pendekatan, pendekatan yang pertama persamaan Meyer Peter dan Muller (MPM), pendekatan yang kedua dengan persamaan Duboys. angkutan sedimen total adalah merupakan jumlah dari angkutan sedimen dasar (bed load) dan angkutan sedimen suspensi (suspended load). Total sedimennya adalah sebagai berikut:

qtot $=q b+q s$ 
Dimana:

qtot $=$ Sedimen total

(ton/th)

$\mathrm{qb}=$ Sedimen mengendap (bed load) (ton/th)

qs = Sedimen melayang (suspended load) (ton/th)

Muatan dasar (bed load) adalah partikel yang bergerak pada dasar sungai dengan cara berguling, meluncur dan meloncat, untuk mengetahui besarnya muatan dasar (qb) sedimen pada penelitian ini didekati dengan Persamaan (Meyer Peter dan Muller (MPM), 1948; Mulyanto, 2007). Adapun persamaannya adalah sebagai berikut:

$\mathrm{qb}=\Phi\left(\mathrm{g} \Delta \mathrm{D}_{50}\right)^{3 / 12}$

Dengan rumus turunan:

$$
\begin{aligned}
\Phi & =\left(4 \Psi^{\prime}-0,188\right)^{3 / 2} \\
\Psi & =\mu \cdot \tau /(\Delta \cdot \rho \mathrm{W} \cdot \mathrm{g} \cdot \mathrm{D} 50) \\
\tau & =\rho w \cdot g \cdot R \cdot I \\
\mu & =\left(\mathrm{C} / \mathrm{C}^{\prime}\right)^{3 / 2} \\
\mathrm{C}^{6} & =18 \log (12 \mathrm{R} / \mathrm{D} 90)
\end{aligned}
$$

Dimana:

$\Phi=$ Parameter angkutan sedimen (ton/tahun)

$$
\begin{array}{ll}
R & =\text { Jari }- \text { jari hidroulis }(\mathrm{m}) \\
\Psi & =\text { Parameter intensitas aliran } \\
\left(\mathrm{m}^{2} / \mathrm{dtk}\right) &
\end{array}
$$$$
\text { D90; } D 50=\text { Diameter butiran }(\mathrm{m})
$$$$
T=\text { Tegangan gesek }(\mathrm{kg} / \mathrm{dtk})
$$$$
g \quad=\text { Gravitasi }(\mathrm{m} / \mathrm{dtk})
$$$$
\mu \quad=\text { Ripple factor }(\mathrm{m} / \mathrm{dtk})
$$$$
\text { I }=\text { Kemiringan dasar sungai }(\mathrm{m})
$$$$
\mathrm{C}^{6} \quad=\text { Koefisien Chezy }
$$

Muatan layang (suspended load) dapat juga dihitung dengan menggunakan rumus USBR (United State Beureu Reclamation) dimana untuk menghitung angkutan muatan layang. Diperlukan pengukuran debit aliran (Qw) dalam $\mathrm{m}^{3 /}$ det, yang dikombinasikan dengan kosentrasi sedimen (Cs) dalam mg/lt, yang menghasilkan debit sedimen dalam ton/hari dihitung dengan persamaan:

Qs $\quad=0,0864$ Cs. Q

Dengan

Cs $=\pi \mathrm{r}^{2} . \mathrm{T}$.

Dimana:

$$
\begin{array}{ll}
\mathrm{qs} & =\text { Debit sedimen }\left(\mathrm{m}^{3} / \mathrm{hari}\right) \\
\mathrm{Cs} & =\text { Kosentrasi sedimen }(\mathrm{mg} / \mathrm{lt}) \\
\mathrm{Q} & =\text { Debit sungai }\left(\mathrm{m}^{3} / \mathrm{det}\right) \\
\mathrm{r} & =\text { Jari-jari botol }(\mathrm{cm}) \\
\mathrm{t} & =\text { Tinggi endapan sedimen di dalam }
\end{array}
$$
botol $(\mathrm{cm})$

Adapun persamaan laju transport material dasar menurut Duboys sebagai berikut:

$$
\mathrm{qb}=\Psi_{\mathrm{D}} \tau_{\mathrm{o}}\left(\tau_{\mathrm{o}}-\tau_{\mathrm{c}}\right)
$$

$\tau_{\mathrm{o}}={ }_{\gamma} \mathrm{DS}_{\mathrm{o}}$

Dimana:

$\mathrm{qb}=$ Laju transpor material dasar per satuan lebar sungai $\left(\mathrm{kg} / \mathrm{s} / \mathrm{m}^{3}\right)$

$\Psi_{\mathrm{D}}=$ Fungsi parameter terhadap ukuran partikel $\left(\mathrm{m}^{3} / \mathrm{kg} / \mathrm{s}\right)$

$\tau_{\mathrm{O}}=$ Tegangan geser dasar $\left(\mathrm{kg} / \mathrm{m}^{2}\right)$

$\tau_{\mathrm{c}}=$ Tegangan tarik kritis $\left(\mathrm{kg} / \mathrm{m}^{2}\right)$

$\mathrm{D}=$ Kedalaman air $(\mathrm{m})$

$\mathrm{S}_{\mathrm{o}} \quad$ Kemiringan energy 


\section{METODE PENELITIAN}

\section{Lokasi Penelitian}

Lokasi penelitian ini dilakukan di hulu Sungai Deniang yang terletak di Desa Cit hingga kawasan hilir bermuara langsung di Pantai Pulau Tiga, Desa Deniang, Kabupaten Bangka. Lama waktu penelitaian terhitung sejak ujian proposal sampai dengan ujian seminar hasil. Adapun Peta lokasi penelitian dapat dilihat pada Gambar 1.

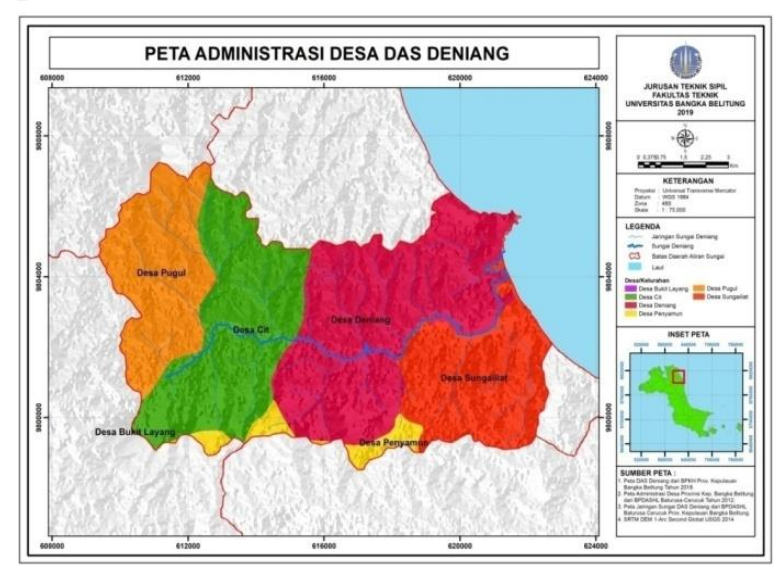

Sumber: BPDASB Bangka Belitung, 2019

Gambar 1 Peta lokasi penelitian

\section{Tahapan Penelitian}

Tahapan penelitian yang dilakukan meliputi Studi literatur. observasi dan pengumpulan data (data primer dan data sekunder). Data primer adalah data yang diperoleh langsung dari lokasi penelitian. Pada penelitian ini data yang dimaksud adalah data sampel sedimen yang berupa sampel sedimen dasar dan sedimen melayang yang diperoleh langsung dari lokasi penelitian. Kemudian, sampel tersebut diuji di Laboratorium untuk pemeriksaan karakteristik sedimen yang berupa kosentrasi sedimen, distribusi ukuran sedimen dan berat jenis sedimen. Data debit aliran berupa data hasil pengukuran kecepatan aliran yang diukur langsung dilokasi penelitian yang selanjutnya dibuat hubungan dengan luas penampang sungai sehingga diperoleh nilai debit air, kemiringan sungai dan kedalaman sungai yang nantinya akan digunakan untuk memperoleh profil dan luas dari penampang sungai. Data Sekunder yaitu peta DAS Deniang, peta kontur diperoleh dari Balai Pengelolaan Daerah Aliran Sungai (BPDAS) Pangkalpinang. Peta jenis tanah, peta tutupan lahan diperoleh dari Badan Pemantapan Kawasan Hutan (BPKH) Wilayah XII Pangkalpinang, data hujan diperoleh dari Badan Meteorologi Klimatologi dan Geofisika (BMKG) Pangkalpinang selama 10 tahun mulai tahun 2009 hingga tahun 2018, setelah data primer dan data sekunder terkumpul tahapan selanjutnya dilakukan analisis secara manual dengan aplikasi dan dengan software SAGA.

\section{HASIL DAN PEMBAHASAN}

\section{Volume Erosi}

1. Faktor Erosivitas Hujan (R)

Erosivitas hujan didefinisikan sebagai jumlah satuan indeks erosi hujan dalam setahun. Nilai R merupakan daya rusak hujan, Suripin (2004). Data hujan yang digunakan untuk menghitung faktor erosivitas hujan adalah data hujan dengan rentang waktu 10 tahun, yaitu data curah hujan dari tahun 2009 sampai tahun 2018, BMKG Pangkalpinang (2018). Faktor erosivitas hujan dapat dicari dengan menggunakan data curah hujan bulanan (cm) dan rumus yang dikemukakan oleh Wischmeier, 1959 (dalam Renard,et.al, 1996), Suripin (2004). Dengan persamaan 
tersebut didapatkan nilai indeks erosivitas hujan rata-rata sebesar 1.986,71.

2. Faktor Erodibilitas Tanah (K)

Jenis tanah pada DAS Deniang teridentifikasi menjadi dua jenis tanah yaitu Alluvium dan Podsolik Kekuningan Klabat Granite, BPKH Wilayah XIII Pangkalpinang (2018). Jenis tanah yang paling dominan adalah Podsolik
Kekuningan Klabat Granite dengan luas wilayah $\pm 6236,6$ Ha $(80,282 \%)$ dengan nilai erodibilitas tanah 0,107 , sedangkan untuk jenis tanah Alluvium memiliki luas wilayah $\pm 1531,74(19,718 \%)$ dengan nilai erodibilitas tanah 0,193. Rekapitulasi jenis tanah pada DAS Deniang tersaji pada Tabel 1.

Tabel 1 Jenis tanah dan nilai erodibilitas tanah DAS Deniang

\begin{tabular}{|c|c|c|c|c|c|}
\hline No & Nama DAS & Jenis tanah & Nilai $K$ & $\begin{array}{c}\text { Luas } \\
\text { (Ha) }\end{array}$ & $\begin{array}{c}\text { Luas } \\
(\%)\end{array}$ \\
\hline 1 & \multirow[b]{2}{*}{ DAS Deniang } & Alluvium & 0,193 & $1.531,74$ & 19,718 \\
\hline 2 & & $\begin{array}{c}\text { Podsolik Kekuningan; } \\
\text { Klabat Granite }\end{array}$ & 0,107 & $6.236,68$ & 80,282 \\
\hline \multicolumn{4}{|c|}{ Jumlah } & 7768,42 & 100 \\
\hline
\end{tabular}

Sumber: BPKH Wilayah XIII Pangkalpinang, 2018

3. Faktor Kemiringan Lereng (LS)

Asdak (2014), mengemukakan bahwa kedudukan lereng juga mnentukan besar kecilnya erosi. Lereng bagian bawah mudah tererosi dari pada bagian atas karena momentum air larian besar dan kecepatan air lebih terkonsentrasi ketika mencapai lereng bagian bawah.Kelas kemiringan lereng DAS Deniang pada Tabel 2 memiliki dominasi oleh kelas 15 $25 \%$ (miring) dengan luas wilayah \pm 4.732,79 Ha (60,923\%). Sedangkan kelas lereng $0-8 \%$ (datar/landai) memiliki luas wilayah $\pm 844,09$ Ha $(10,866 \%)$, kelas lereng 8 - 15\% (agak miring) memiliki luas wilayah $\pm 387,08 \mathrm{Ha}(4,983 \%)$, kelas lereng 25 - 40\% (curam) memiliki luas wilayah $\pm 758,11 \mathrm{Ha}(9,759 \%)$, dan untuk kelas lereng $>40 \%$ (sangat curam) memiliki luas wilayah $\pm 1046,35 \mathrm{Ha}$ $(13,469 \%)$.Nilai faktor panjang dan kemirtingan lereng dapat dilihat pada Tabel 2.

Tabel 2. Hasil perhitungan nilai faktor panjang dan kemiringan lereng (LS)

\begin{tabular}{|c|c|c|c|c|c|}
\hline No & Nama DAS & $\begin{array}{c}\text { Lereng } \\
(\%)\end{array}$ & Nilai LS & Luas (Ha) & Luas (\%) \\
\hline 1 & \multirow{5}{*}{ DAS Deniang } & $0-8 \%$ & 0,4 & 844,09 & 10,866 \\
\hline 2 & & $8-15 \%$ & 1,4 & 387,08 & 4,983 \\
\hline 3 & & $15-25 \%$ & 3,1 & $4.732,79$ & 60,923 \\
\hline 4 & & $25-40 \%$ & 6,8 & 758,11 & 9,759 \\
\hline 5 & & $>40 \%$ & 9,5 & $1.046,35$ & 13,469 \\
\hline \multicolumn{4}{|c|}{ Jumlah } & $7.768,42$ & 100 \\
\hline
\end{tabular}

Sumber: Hasil Penelitian, 2019 
4. Nilai Pengelolaan Tanaman (C)

Faktor C dipengaruhi oleh vegetasi, kondisi permukaan tanah, dan pengelolaan lahan terhadap besarnya tanah yang hilang (erosi), Suripin (2004). Nilai faktor pengelolaan tanaman (C) ditentukan berdasarkan jenis tutupan lahan dan pengelolaan lahan pada setiap unit lahan di DAS Deniang. Nilai faktor $\mathrm{C}$ dapat dilihat pada Tabel 3.

Tabel 3. Nilai faktor tanaman atau tutupan lahan DAS Deniang

\begin{tabular}{|c|c|c|c|c|c|}
\hline No & Nama DAS & Tutupan lahan & Nilai $\mathrm{C}$ & Luas (Ha) & Luas (\%) \\
\hline 1 & \multirow{6}{*}{ DAS Deniang } & Semak Belukar & 0,3 & 9,25 & 0,119 \\
\hline 2 & & Perkebunan & 0,4 & 324,65 & 4,179 \\
\hline 3 & & Tanah Terbuka & 1 & 739,10 & 9,514 \\
\hline 4 & & $\begin{array}{c}\text { Pertanian Lahan } \\
\text { Kering }\end{array}$ & 0,1 & $1.868,08$ & 24,047 \\
\hline 5 & & $\begin{array}{c}\text { Pertanian Lahan } \\
\text { Kering Campur } \\
\text { Semak }\end{array}$ & 0,1 & $3.454,45$ & 44,468 \\
\hline 6 & & Pertambangan & 1 & $1.372,90$ & 17,673 \\
\hline \multicolumn{4}{|c|}{ Jumlah } & $7.768,42$ & 100 \\
\hline
\end{tabular}

Sumber: BPKH Wilayah XIII Pangkalpinang, 2018

Jenis tutupan lahan DAS Deniang pada Tabel 3. memiliki dominasi oleh jenis tutupan lahan pertanian lahan kering campur semak dengan luas wilayah \pm $3.454,45 \mathrm{Ha}(44,468 \%)$. Sedangkan oleh jenis tutupan lahan semak belukar dengan luas wilayah $\pm 9,25 \mathrm{Ha}(0,119 \%)$, jenis tutupan lahan perkebunan dengan luas wilayah $\pm 324,65 \mathrm{Ha} \quad(4,179 \%)$, jenis tutupan lahan tanah terbuka dengan luas wilayah $\pm 739,10 \mathrm{Ha}(9,514 \%)$, jenis tutupan lahan pertanian lahan kering dengan luas wilayah $\pm 1.868,08 \mathrm{Ha}$ $(24,047 \%)$ dan jenis tutupan lahan pertambangan dengan luas wilayah \pm $1.372,90 \mathrm{Ha}(17,673 \%)$.

\section{Nilai Pengelolaan Lahan (P)}

Nilai faktor tindakan manusia dalam konservasi tanah $(\mathrm{P})$ adalah nisbah antara besarnya erosi dari lahan dengan suatu tindakan konservasi tertentu terhadap besarnya erosi pada lahan tanpa tindakan konservasi, Suripin (2004). Berdasarkan pengamatan lapangan diketahui pengelolaan lahan di sepanjang DAS Deniang tidak dilakukan pengelolaan lahan. Selain banyaknya lahan bekas pertambangan (kulong), lahan berpasir terbuka, diperparah tidak ada tindakan konservasi sama sekali yang dilakukan baik oleh pemerintah setempat apalagi masyarakat. Sehingga untuk nilai pengelolaan lahan $(\mathrm{P})$ dikatagorikan tanpa ada tindakan konservasi nilai $\mathrm{P}=1$.

Klasifikasi erosi dibagi dalam 5 kelas, mulai dari kelas sangat ringan, ringan, sedang, berat sampai sangat berat. Berikut klasifikasi kelas bahaya erosi dapat dilihat pada Tabel 4. 
Tabel 4. Klasifikasi kelas bahaya erosi

\begin{tabular}{|c|c|c|}
\hline Kelas Bahaya Erosi & A (Ton/Ha/Tahun) & Keterangan \\
\hline I & $<15$ & Sangat Ringan \\
\hline II & $15-60$ & Ringan \\
\hline III & $60-180$ & Sedang \\
\hline IV & $180-480$ & Berat \\
\hline V & $>480$ & Sangat Berat \\
\hline
\end{tabular}

Sumber: Suripin, 2004

Besarnya erosi pada DAS Deniang dapat dihitung dengan cara mengalikan faktor-faktor erosi menggunakan metode USLE yaitu faktor Erosivitas Hujan (R), Erodibilitas Tanah (K), Panjang dan Kemiringan Lereng (LS) dan faktor pengelolaan tanaman (C) dan tindakan konservasi tanah (P), Suripin (2004). Maka besarnya volume erosi yang terjadi pada daerah penelitian sebesar 334,234 Ton/Ha/Tahun dengan klasifikasi bahaya erosi kelas IV (Berat).

\begin{tabular}{|c|c|c|c|c|c|}
\hline \multirow{2}{*}{ No } & \multirow{2}{*}{$\begin{array}{l}\text { Kode } \\
\text { satuan } \\
\text { lahan } \\
\end{array}$} & \multirow{2}{*}{ Luas (Ha) } & \multicolumn{2}{|l|}{$\mathbf{A}$} & \multirow{2}{*}{ Erosi rata-rata } \\
\hline & & & Ton/ Ha/Tahun & Ton/Tahun & \\
\hline \multirow{2}{*}{\multicolumn{5}{|c|}{ 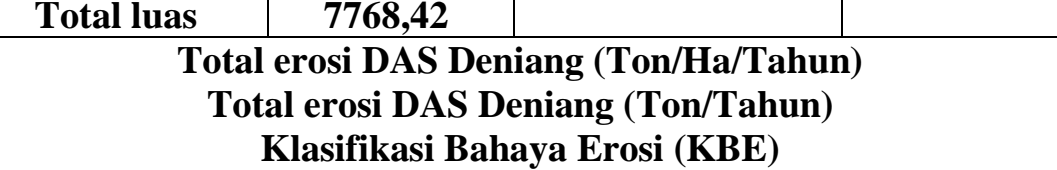 }} & \\
\hline & & & & & $\begin{array}{c}334,234 \\
2.596 .471,761 \\
\text { Kelas IV (Berat) }\end{array}$ \\
\hline
\end{tabular}

\section{Volume Sedimen}

\section{Sedimen Melayang}

Dari hasil pemeriksaan dan hilir sungai $0,73 \mathrm{~cm}$. Ketinggian sedimen perhitungan diperoleh nilai berat jenis sedimen (Gs) 2,660, Hasil pengambilan sampel disetiap titik kemudian dilakukan perhitungan volume sedimen untuk mencari konsentrasi sedimen (Cs) setiap sampel. Dari bentuk fisiknya sedimen merupakan pasir campuran lempung lanau dengan tinggi sedimen pada Sungai Deniang dibagian hulu sebesar $0,34 \mathrm{~cm}$, terukur dalam wadah botol setiap $1,5 \mathrm{ml}$ sampel yang diambil. kemudian dengan menggunakan persamaan 5, besar konsentrasi sedimen (Cs) di hulu, tengah dan hilir akan didapatkan, dan setelah mendapatkan nilai konsentrasi sedimen selanjutnya dihitung debit sedimen melayang (qs) dengan hasil seperti pada Tabel5.

bagian tengah sungai $0,62 \mathrm{~cm}$, dan bagian

Tabel 5. Perhitungan Konsentrasi Sedimen dan Debit Melayang

\begin{tabular}{|c|c|c|c|c|c|c|c|}
\hline $\begin{array}{c}\text { Bagian } \\
\text { sungai }\end{array}$ & $\begin{array}{c}\text { Tinggi } \\
\text { sedimen } \\
(\mathbf{c m})\end{array}$ & $\boldsymbol{\pi}$ & $\mathbf{r}(\mathbf{c m})$ & $\begin{array}{c}\text { Ukuran } \\
\text { botol }(\mathbf{l})\end{array}$ & $\mathbf{Q} \mathbf{~ m}^{\mathbf{3}} / \mathbf{s}$ & $\begin{array}{c}\mathbf{C s} \\
\left(\mathbf{m}^{\mathbf{3}} / \mathbf{l}\right)\end{array}$ & $\begin{array}{c}\mathbf{q S} \\
(\text { ton/tahun })\end{array}$ \\
\hline Hulu & 0,34 & 3,14 & 4,28 & 1,5 & 0,417 & 0,00001304 & 21,776 \\
\hline
\end{tabular}




\begin{tabular}{|c|c|c|c|c|c|c|c|}
\hline $\begin{array}{c}\text { Bagian } \\
\text { sungai }\end{array}$ & $\begin{array}{c}\text { Tinggi } \\
\text { sedimen } \\
(\mathbf{c m})\end{array}$ & $\boldsymbol{\pi}$ & $\mathbf{r}(\mathbf{c m})$ & $\begin{array}{c}\text { Ukuran } \\
\text { botol }(\mathbf{l})\end{array}$ & $\mathbf{Q} \mathbf{~ m}^{\mathbf{3}} / \mathbf{s}$ & $\begin{array}{c}\mathbf{C s} \\
\left(\mathbf{m}^{\mathbf{3}} / \mathbf{l}\right)\end{array}$ & $\begin{array}{c}\mathbf{q s} \\
(\text { ton/tahun) }\end{array}$ \\
\hline Tengah & 0,62 & 3,14 & 4,28 & 1,5 & 17,298 & 0,00002377 & $1.647,218$ \\
\hline Hilir & 0,73 & 3,14 & 4,28 & 1,5 & 16,662 & 0,00002799 & $1.868,158$ \\
\hline
\end{tabular}

Sumber: Hasil Analisis, 2019

\section{Sedimen Dasar}

Penentuan diameter sedimen melalui percobaan analisa saringan yang dilakukan di Laboratorium, sehingga dari hasil percobaan tersebut dapat kita peroleh nilai diameter butiran yang seragam atau $D_{50}$ dan $\mathrm{D}_{90}$ dari sedimen tersebut. Adapun nilai diameter butiran sedimen $D_{50}$ yaitu sebesar 1,2 mm dan $\mathrm{D}_{90}$ sebesar 2,02 $\mathrm{mm}$.

Perhitungan jumlah debit yang dihasilkan pada tiap bagian sungai yang disajikan pada Tabel 6 .

Tabel 6. Hasil perhitungan kecepatan dan debit pada setiap bagian sungai

\begin{tabular}{|c|c|c|c|c|c|c|}
\hline $\begin{array}{l}\text { Bagian } \\
\text { sungai }\end{array}$ & Pias & Bentuk pias & $\begin{array}{c}\mathbf{A} \\
\left(\mathbf{m}^{2}\right)\end{array}$ & $\begin{array}{c}\text { A Total } \\
\left(\mathbf{m}^{2}\right)\end{array}$ & $\mathbf{V}(\mathbf{m} / \mathbf{s})$ & $\mathbf{Q}\left(\mathrm{m}^{3} / \mathrm{s}\right)$ \\
\hline \multirow{5}{*}{ Hulu } & HU1 - HU2 & Segitiga & 0,092 & \multirow{5}{*}{0,892} & \multirow{5}{*}{0,468} & \multirow{5}{*}{0,417} \\
\hline & HU2 - HU3 & Trapesium & 0,270 & & & \\
\hline & HU3 - HU4 & Trapesium & 0,244 & & & \\
\hline & HU4 - HU5 & Trapesium & 0,225 & & & \\
\hline & HU5 - HU6 & Segitiga & 0,062 & & & \\
\hline \multirow{7}{*}{ Tengah } & TE1 - TE2 & Trapesium & 2,178 & \multirow{7}{*}{28,218} & \multirow{7}{*}{0,613} & \multirow{7}{*}{17,298} \\
\hline & TE2 - TE3 & Trapesium & 3,738 & & & \\
\hline & TE3 - TE4 & Trapesium & 5,011 & & & \\
\hline & TE4 - TE5 & Trapesium & 1,366 & & & \\
\hline & TE5 - TE6 & Trapesium & 2,882 & & & \\
\hline & TE6 - TE7 & Trapesium & 11,869 & & & \\
\hline & TE7 - TE8 & Trapesium & 1,175 & & & \\
\hline \multirow{5}{*}{ Hilir } & HI1 - HI2 & Segitiga & 1,365 & \multirow{5}{*}{17,897} & \multirow{5}{*}{0,931} & \multirow{5}{*}{16,662} \\
\hline & HI2 - HI3 & Trapesium & 5,755 & & & \\
\hline & HI3 - HI4 & Trapesium & 5,053 & & & \\
\hline & HI4 - HI5 & Trapesium & 4,580 & & & \\
\hline & HI5 - HI6 & Segitiga & 1,144 & & & \\
\hline
\end{tabular}

Selanjutnya setelah mendapatkan data diameter butir, kecepatan aliran dan debit pada bagian sungai maka sedimen dasar dapat ditentukan dengan menggunakan persamaan 3 .

\section{Metode Duboys}

Berdasarkan hasil analisis sedimen dasar menurut Duboys menggunakan persamaan 6 dan persamaan 7, sehingga diperoleh hasil seperti Tabel 7. 
Tabel 7 Perhitungan sedimen dasar menurut Duboys

\begin{tabular}{|c|c|c|c|c|c|c|c|c|c|c|}
\hline Bagian & $\mathbf{d}_{\mathbf{5 0}}$ & $\gamma$ & D & $\mathbf{S}$ & $\tau_{0}$ & $\tau_{\mathrm{c}}$ & $\Psi_{D}$ & $\mathbf{q}_{b}$ & $\begin{array}{c}q_{b} \\
\text { Satuan } \\
\text { lebar }\end{array}$ & $\mathbf{q}_{\mathbf{b}}$ \\
\hline & $(\mathrm{m})$ & & (m) & & $\begin{array}{l}(\mathrm{kg} / \\
\left.\mathrm{m}^{2}\right)\end{array}$ & $\begin{array}{l}(\mathrm{kg} / \\
\left.\mathrm{m}^{2}\right)\end{array}$ & $\begin{array}{c}\left(\mathrm{m}^{3} / \mathrm{kg} /\right. \\
\mathrm{s})\end{array}$ & $\begin{array}{c}(\mathrm{kg} / \mathrm{s} / \\
\left.\mathrm{m}^{3}\right)\end{array}$ & $(\mathrm{kg} / \mathrm{s})$ & ton/tahun \\
\hline Hulu & 0,00066 & 1000 & 0,44 & $\begin{array}{c}0,001 \\
75\end{array}$ & 0,77 & $\begin{array}{c}0,126 \\
9\end{array}$ & $\begin{array}{c}0,0016 \\
0\end{array}$ & $\begin{array}{c}0,000 \\
793\end{array}$ & 0,00293 & 92,348 \\
\hline Tengah & 0,00049 & 1000 & $\begin{array}{c}1,22 \\
3\end{array}$ & $\begin{array}{c}0,001 \\
75\end{array}$ & $\begin{array}{c}2,140 \\
3\end{array}$ & $\begin{array}{c}0,107 \\
4\end{array}$ & $\begin{array}{c}0,0012 \\
7\end{array}$ & $\begin{array}{c}0,005 \\
543\end{array}$ & 0,19270 & $\begin{array}{c}6.081,32 \\
6\end{array}$ \\
\hline Hilir & 0,0012 & 1000 & $\begin{array}{c}1,68 \\
5\end{array}$ & $\begin{array}{c}0,001 \\
75\end{array}$ & $\begin{array}{c}2,948 \\
8\end{array}$ & $\begin{array}{c}0,170 \\
9\end{array}$ & $\begin{array}{c}0,0024 \\
0\end{array}$ & $\begin{array}{c}0,002 \\
401\end{array}$ & 0,33789 & $\begin{array}{c}10.663,1 \\
23\end{array}$ \\
\hline
\end{tabular}

Sumber: Hasil Analisis, 2019

Metode Meyer Peter Muller

Berdasarkan hasil analisis sedimen dasar menurut Duboys menggunakan persamaan 3, 4 dan 5. sehingga diperoleh hasil seperti Tabel 8.

Tabel 8. Perhitungan sedimen dasar menurut Meyer Peter Muller

\begin{tabular}{|c|c|c|c|c|}
\hline \multirow{2}{*}{ Simbol } & \multirow{2}{*}{ Satuan } & \multicolumn{3}{|c|}{ Bagian sungai } \\
\cline { 3 - 5 } & & Hulu & Tengah & Hilir \\
\hline $\mathrm{d} 50$ & $\mathrm{~m}$ & 0,00066 & 0,00049 & 0,0012 \\
\hline $\mathrm{d} 90$ & $\mathrm{~m}$ & 0,0019 & 0,00075 & 0,00202 \\
\hline $\mathrm{y}$ & $\mathrm{m}$ & 0,440 & 1,223 & 1,685 \\
\hline $\mathrm{R}$ & $\mathrm{m}$ & 0,220 & 0,612 & 0,843 \\
\hline $\mathrm{C}$ & & 56,571 & 71,829 & 66,589 \\
\hline $\mathrm{I}$ & & 0,00175 & 0,00175 & 0,00175 \\
\hline $\mathrm{V}$ & $\mathrm{m} / \mathrm{s}$ & 0,468 & 0,613 & 0,931 \\
\hline $\mathrm{C}$ & $\mathrm{m} / 5 / \mathrm{s}$ & 23,851 & 18,739 & 24,246 \\
\hline$\mu$ & $\mathrm{m} / \mathrm{s}$ & 0,2738 & 0,1332 & 0,2197 \\
\hline $\mathrm{r} w$ & $\mathrm{~kg} / \mathrm{m}^{3}$ & 1000 & 1000 & 1000 \\
\hline $\mathrm{g}$ & $\mathrm{m} / \mathrm{s}$ & 9,8 & 9,8 & 9,8 \\
\hline $\mathrm{t}$ & $\mathrm{kg} / \mathrm{s}$ & 3,773 & 10,487 & 14,449 \\
\hline $\mathrm{D}$ & $\mathrm{kg} / \mathrm{m}^{3}$ & 1,65 & 1,65 & 1,65 \\
\hline $\mathrm{Y}$ & $\mathrm{m} / \mathrm{s}$ & 0,0968 & 0,1764 & 0,1636 \\
\hline $\mathrm{F}$ & $\mathrm{m} / \mathrm{s}$ & 0,0889 & 0,3722 & 0,3186 \\
\hline \multirow{2}{*}{$\mathrm{qb}$} & $\mathrm{m}^{3} / \mathrm{tahun}$ & 191,085 & 512,012 & $1.679,262$ \\
\cline { 2 - 5 } & ton/tahun & $\mathbf{2 8 0 , 8 9}$ & $\mathbf{7 5 2 , 6 5 8}$ & $\mathbf{2 . 4 6 8 , 5 1 5}$ \\
\hline
\end{tabular}

Total Sedimen

Setelah sedimen melayang dan sedimen dasar didapatkan maka akan diperoleh total sedimen dengan menggunakan persamaan 2, sehingga diperoleh hasil seperti pada Tabel 9. 
Tabel 9. Perhitungan sedimen total Sungai Deniang

\begin{tabular}{|c|c|c|c|c|c|}
\hline \multirow{2}{*}{ Bagian } & \multicolumn{2}{|c|}{$\begin{array}{c}\text { Sedimen dasar qb } \\
\text { (ton/tahun) }\end{array}$} & $\begin{array}{c}\text { Sedimen } \\
\text { melayang qs } \\
\text { (ton/tahun) }\end{array}$ & \multicolumn{2}{|c|}{ Sedimen total qtot (ton/tahun) } \\
\cline { 2 - 6 } & $\begin{array}{c}\text { Duboys } \\
(\mathbf{A})\end{array}$ & $\begin{array}{c}\text { Meyer } \\
\text { Peter } \\
\text { Muller (B) }\end{array}$ & (C) & $\begin{array}{c}\text { Duboys } \\
(\mathbf{A}+\mathbf{C})\end{array}$ & $\begin{array}{c}\text { Meyer } \\
\text { Peter } \\
\text { Muller } \\
\text { (B+C) }\end{array}$ \\
\hline Hulu & 92,348 & 280,89 & 21,776 & 114,124 & 302,671 \\
\hline Tengah & 6081,327 & 752,658 & 1647,218 & 7728,545 & 2399,876 \\
\hline Hilir & 10663,123 & 2468,515 & 1868,158 & 12531,282 & 4336,673 \\
\hline
\end{tabular}

Sumber: Hasil Analisis, 2019

Perbandingan Hasil Sedimentasi dan Erosi di DAS Deniang

Perbandingan Sedimentasi dilakukan untuk mencari selisih hasil dari sedimentasi dan erosi yang ada di DAS
Deniang. Untuk perhitungan sedimentasi menggunakan metode Duboys dan Mayer Peter Muller, sedangkan untuk perhitungan erosi menggunakan metode USLE. Adapun hasil yang didapat disajikan pada Tabel 10.

Tabel 10. Perbandingan hasil erosi dan sedimentasi di DAS Deniang

\begin{tabular}{|c|c|c|c|c|c|c|}
\hline \multirow{2}{*}{ No } & \multirow{2}{*}{$\begin{array}{c}\text { Nama } \\
\text { DAS }\end{array}$} & \multirow{2}{*}{$\begin{array}{l}\text { Luas } \\
\text { DAS }\end{array}$} & \multirow{2}{*}{$\begin{array}{l}\text { Bagian } \\
\text { sungai }\end{array}$} & \multicolumn{2}{|c|}{$\begin{array}{c}\text { Sedimen total } \\
\text { (Ton/Tahun) }\end{array}$} & $\begin{array}{c}\text { Erosi } \\
\text { (Ton/Tahun) }\end{array}$ \\
\cline { 4 - 6 } & & & Duboys & MPM & Metode USLE \\
\hline 1 & \multirow{2}{*}{$\begin{array}{c}\text { DAS } \\
\text { Deniang }\end{array}$} & \multirow{2}{*}{7768,42} & Hulu & 114,124 & 302,671 & \\
\cline { 1 - 3 } 2 & & Tengah & $7.728,545$ & $2.399,876$ & \multirow{2}{*}{$2.596 .471,761$} \\
\cline { 1 - 3 } & & Hilir & $12.531,282$ & 4336,673 & \\
\hline \multicolumn{3}{|c|}{ Jumlah } & & $20.373,951$ & 7039,219 & \\
\hline
\end{tabular}

Sumber: Data diolah, 2019

Dari hasil yang didapat, load). Perhitungan sedimen hanya perbandingan antara erosi dan sedimentasi di DAS Deniang memiliki perbandingan yang tidak wajar karena selisih antara hasil erosi dan sedimentasi terlalu jauh. Perbandingan jauh tersebut dikarenakan perhitungan erosi menggunakan metode USLE yang dimana metode tersebut hanya dapat menghitung erosi permukaan dan tidak memperhitungkan hasil sedimen erosi parit, tebing sungai dan dasar sungai. Sedangkan sedimen sendiri merupakan hasil sedimentasi yang berada di aliran sungai yaitu berupa sedimen melayang (suspended load) dan mengendap (bed dianalisis di bagian hulu, tengah dan hilir. Besarnya jumlah erosi yang terjadi di DAS Deniang akibat pengaruh tataguna lahan yang buruk yaitu berupa aktivitas penambangan yang berada disamping sungai.

\section{KESIMPULAN}

1. Hasil erosi total yang dihitung dengan menggunakan metode USLE didapatkan hasil erosi sebesar 2.596.471,761 Ton/Tahun dengan kelas bahaya erosi kelas IV (berat). 
2. Total sedimen yang terjadi di Sungai Deniang menggunakan metode Duboys pada bagian hulu sebesar 114,124 Ton/Tahun, bagian tengah 7.728,545 Ton/Tahun dan pada bagian hilir sebesar 12.531,282 Ton/Tahun. Kemudian hasil sedimen total menggunakan rumus Meyer Peter Muller dibagian hulu sebesar 302,671 Ton/Tahun, bagian tengah $2.399,876$ Ton/Tahun dan pada bagian hilir sebesar 4336,673 Ton/Tahun.

\section{DAFTAR PUSTAKA}

Asdak. C, 2014, Hidrologi dan Pengelolaan Daerah Aliran Sungai, Cetakan Ke-6, Gadjah Mada University Press, Yogyakarta.

Adrianto, Bayu, dkk, 2017, Analisa Laju Sedimentasi di Muara Sungai Karangsong Kabupaten Indramayu, Jurnal, Jurusan Oseanografi, Fakultas Perikanan dan Ilmu Kelautan, Universitas Diponegoro, Semarang.

Balai Pengelolaan Daerah Aliran Sungai (BPDAS) Pangkalpinang, 2018, peta DAS Deniang.

Badan Pemantapan Kawasan Hutan (BPKH) Wilayah XIII Pangkalpinang, 2018, Peta jenis tanah, peta tutupan lahan.
Badan Meteorologi Klimatologi dan Geofisika (BMKG) Pangkalpinang, 2018, data hujan.

Banuwa, I. S, 2013, Erosi, Prenadamedia Group, Jakarta.

Maulana,S., 2011, Analisis Angkutan Sedimen Muara Air Kantung Sungailiat Kabupaten Bangka (Tugas Akhir), Fakultas Teknik Universitas Bangka Belitung.

Mulyanto,H.R., 2007, Sungai Fungsi dan Sifat-sifatnya, Graha Ilmu, Yogyakarta.

Suripin., 2004, Pelestarian Sumber Daya Tanah dan Air, Andi, Yogyakarta.

Maksud dari perjalanan

Sabri, F., 2017, Kajian Erosi dan Sedimentasi Akibat Perubahan Tataguna Lahan Daerah Aliran Sungai (Studi Kasus DAS Betung Sub DAS Pebari-Jelitik Kabupaten Bangka), Prosiding Seminar Nasional Pengelolaan Daerah Aliran Sungai Secara Terpadu, Jurusan Teknik Sipil, Fakultas Teknik, Universita Bangka Belitung.

Sembiring, Amelia, dkk, 2014, Analisis Sedimentasi di Muara Sungai Penasen, Jurnal, Jurusan Teknik Sipil, Fakultas Teknik, Universitas Sam Ratulangi, Manado. 